\title{
Determining Factors of Students' Satisfaction with Malaysian Skills Training Institutes
}

\author{
Mohd Zuhdi Ibrahim ${ }^{1}$, Mohd Nizam Ab Rahman ${ }^{1}$ \& Ruhizan M. Yasin ${ }^{2}$ \\ ${ }^{1}$ Faculty of Engineering \& Built Environment, Universiti Kebangsaan Malaysia, Bangi, Selangor, Malaysia \\ ${ }^{2}$ Faculty of Education, Universiti Kebangsaan Malaysia, Bangi, Selangor, Malaysia \\ Correspondence: Mohd Zuhdi Ibrahim, Faculty of Engineering \& Built Environment, Universiti Kebangsaan \\ Malaysia, Bangi, Selangor, Malaysia. Tel: 60-12-315-2385. E-mail: mzuhdi@eng.ukm.my
}

\author{
Received: February 12, 2014 Accepted: April 23, 2014 Online Published: May 20, 2014 \\ doi:10.5539/ies.v7n6p9 URL: http://dx.doi.org/10.5539/ies.v7n6p9
}

\begin{abstract}
The purpose of this study is to examine students' perception of quality of service offered in Malaysian skills training institutes and how it influences overall satisfaction. This study employed a questionnaire survey involving seven skills training institutes in Klang Valley, Malaysia. From 600 questionnaires distributed, 419 were returned (69.8 percent response rate). Causation relationship was analysed using Partial Least Squares Structural Equation Modelling technique. Results show that campus environment was the most significant predictor of student satisfaction, followed by management of institute and support services. Interestingly, the study found that physical facilities and training delivery were not significant predictors of students' overall satisfaction. Enriching knowledge in service quality and customer satisfaction is important for skills training institutes to identify priorities for performance improvement. The implication of this finding is deemed valuable and useful for institution management, policymakers and researchers in the training and educational sector.
\end{abstract}

Keywords: service quality, skills training, students' satisfaction, structural equation modeling, partial least square

\section{Introduction}

Currently, the education and training institutions face competition caused by the globalisation and limited funds allocated by the government (Abdullah, 2006b). Normally, the discussions about quality in education emphasise quality related to the stakeholders. One of the main stakeholders of the educational institutions is the students, who are the key element in the learning and teaching process (Gallifa \& Batalle, 2010). Training institutions are responsible for providing the highest service quality possible to students. Service quality has received significant attention (Abdullah, 2006a). Services delivered by a training provider can be observed from the viewpoint of students as the main customers (Hill, Lomas, \& MacGregor, 2003). Thus, quality of service is crucial for training institutions to compete in the current local and global arena. The forces driving the continuous improvement of service quality included increased competition for resources, instructors, and students, as well as ever-increasing demands from stakeholders for quality and accountability (Shelnutt \& Buch, 1996).

The usual approach of assessing the quality of education inputs, for example measurement of cost per student, library capacity, the number of trainers and so forth, are no longer adequate (McCoy, Chamberlain, \& Seay, 1994). Similarly, a management approach focused only on standards, accreditation, and performance indicators are inadequate. Performances of educational institutions are often evaluated in terms of activities compared to service quality provided to students (Hattie, 1990). Hittman (1993) also criticised the traditional approach in the quality assessment of educational institutions that are too focused on academic quality with limited attention to other aspects of the students' learning experience. This approach fails to comprehensively improve the quality of education. Educational institutions should also pay attention to the perception of their students' learning experience. There is little attention and research that focuses on student feedback as the major customer (Abdullah, 2006a).

Based on the definition of quality by Grönroos (1984), the quality must be evaluated by the users or consumers of the service. Studies by Owlia and Aspinwall (1997) concluded that a customer oriented approach principle can be accepted in the educational sector. Measurement of the outcome is the latest approach in quality assessment 
including students' perceptions of educational quality (Mollis \& Marginson, 2002). Students' views and feedback are important determinants or critical factors of performance indicators of educational institutions. Students' perception of quality is an important variable to be studied and it is associated with any definition of quality.

Therefore, there is a rationale for measuring quality not only in academic elements but must include all components encompassing all services available to students. It is crucial for determining critical factors of quality from the customer's viewpoint. The perception of quality is particularly relevant for the quality of educational outcomes. Obtaining responses from the students is a must to manage service quality. Feedback is highly useful for evaluation and improvement (Abili, Thani, Mokhtarian, \& Rashidi, 2011). Recently, measuring student satisfaction in the education sector has become compulsory (J. Douglas, A. Douglas, \& Barnes, 2006). Measuring students' perception of their study experiences and other activities is deemed important (Rowley, 2003).

Perfomance of quality in the service sector is hard to manage because of intangible attributes (Thakkar, Deshmukh, \& Shastree, 2006). These attributes are also valid in the training and educational sectors. As suggested by Shank et al. (1995), educational service has all the attributes of the service industry that are intangible, heterogeneous, inseparable, variable, and perishable. The educational sector is unique because of faculty autonomy and the accompanying struggle when concentrating on several categories of customers and stakeholders.

The training organisations should understand the customer's requirements and expectations for service quality offered to them (Sahney, Banwet, \& Karunes, 2004). Elements that can impact student expectations have to be recognised. As pointed out by several scholars (Debnath \& Shankar, 2012; Ghazali, 2008; Tsinidou, Gerogiannis, \& Fitsilis, 2010; Yusof, 2008), quality of services offered by training organisations becomes vital for determining their existence. This subject is a key interest of this research which examines how training institutes can satisfy students and attract more and continuous enrolment.

As an accreditation agency, the Department of Skills Development, Ministry of Human Resources, Malaysia received a lot of complaints from the students and parents regarding the services offered by training institutions in Malaysia. The complaints concerned the quality of instructors, the management of the institutes, training delivery and infrastructure and facilities. The instructor complaints related to the instructor's qualification and capability, inadequate numbers and high turnover of instructors. Complaints related to the management of the institute included breaking promises, ineffective financial management, student feedback being ignored, incompetent management, and delayed processes. The complaints related to the training delivery included insufficient practical training, too focused on theory, improper documentation, ineffective student evaluation processes, incomplete training materials, and exceeding quota for number of students. Infrastructure problems included classroom conditions being non-conducive, inadequate and poorly maintained workshop facilities and equipment, layout and physical conditions, teaching equipment, workshop safety not enforced, and equipment and learning materials not working.

Thus, a study to investigate the details of the problems regarding quality of services offered by training institutions in Malaysia is needed. This study focuses on the students' feedback towards the services provided by training institutes and to identify overall student satisfaction. The hypotheses concern service quality dimensions, including the following: campus environment; physical facilities; training equipment; instructor; training curriculum; training delivery; support services; library; and management of the institute-a significant predictor of overall student satisfaction. This research has important implications, as its findings may assist skills training institutions to identify which areas require greater attention to increase service quality. In addition, the concepts and practices of service quality are not sufficiently developed in the skills training sector. Contemporary literature in quality management tends to focus on manufacturing and other service sectors, with few empirical studies in the skills training sector.

This paper is organised into several sections, beginning with an introduction and theoretical background on skills training in Malaysia, service quality in education and training, and student satisfaction. Methodology of the study, covering data collection procedure and data analysis, is discussed as well. Results focus on assessment of measurement instrument and hypothesis testing. Lastly, a discussion, conclusion and recommendations are provided.

\section{Theoretichal Background}

\subsection{Implementation of Skills Training in Malaysia}

The Malaysian tertiary education system can be categorised into three sectors: skills training, vocational and 
technical education, and higher education, (Malaysian Qualification Agency, 2011). Every sector has its own objectives when preparing human resources for the growth of the country.

Vocational education or skills training prepare students for occupations at different levels. It is occasionally denoted as technical education, as the student directly develops a skill with a specific set of techniques. As explained by Brown (2011), vocational education and training (VET) in Australia is perceived as delivering 'knowledge and skills for particular occupations whereas the higher education sector has variously been defined as providing a general mechanism for economic and social change as well as research and teaching to further understanding and the development of knowledge' (O'Shea, Lysaght, \& Tanner, 2012, p. 2).

There are dissimilarities between the two sectors in terms of approach (competency-based for VET, skills and knowledge for higher education), accreditation, governance, and funding arrangements. The VET sector offers many benefits, particularly for those who have low academic achievement in school. The main difference appears to be that university graduates aim for professional and management jobs, while VET graduates focus on technical and associate professional, trade, and other occupations.

Table 1. Malaysian skills certification framework

\begin{tabular}{ll}
\hline Qualification awarded & \multicolumn{1}{c}{ Competencies achieved } \\
\hline $\begin{array}{l}\text { Level } 5 \text { (Malaysian Skills } \\
\text { Advance Diploma) }\end{array}$ & $\begin{array}{l}\text { Possession of the required capability to be able to apply a significant range of } \\
\text { fundamental principles and complex techniques through a wide and often } \\
\text { unpredictable variety of contexts }\end{array}$ \\
Level 4 (Malaysian Skill & $\begin{array}{l}\text { Competent in the execution of a wide range of complex technical or professional } \\
\text { work with a significant level of personal responsibility and autonomy }\end{array}$ \\
Diploma) & $\begin{array}{l}\text { Competencies in execution of a wide range of mixed work activities in a variety of } \\
\text { contexts, most of which are complex and non-routine }\end{array}$ \\
Certificate) & $\begin{array}{l}\text { Competent in the execution of a significant range of varied work activities in a variety } \\
\text { of contexts. Some are non-routine, demanding individual responsibility and } \\
\text { Level 2 (Malaysian Skill } \\
\text { Certificate) }\end{array}$ \\
self-sufficiency \\
Compel 1 (Malaysian Skill \\
Certificate)
\end{tabular}

In Malaysia, standardisation and certification system of skills training sector is based on the National Occupational Skill Standards (NOSS). The qualification framework and its explanation are depicted in Table 1 (Yunos, Ahmed, Kaprawi, \& Razally, 2006).

This framework is quite similar to other countries because the definition of qualification is a shared concept. For example, qualification at Level 1 is related to competency in routines and predictable tasks with guidance or supervision. In the United Kingdom Qualification Framework, "ability to apply learning with guidance or supervision" and "activities which mostly related to everyday situations" is defined as Level 1 qualification. This definition is also similar to Mexico's framework, in which Level 1 qualification is to "perform a small group of varied work activities that are mainly routine and predictable" (Tuck, 2007). The complexity and responsibility of the job are becoming increasingly parallel to the level of qualification. Qualification in Level 5 involves application of fundamental knowledge and techniques to solve a wide range and unpredictable variety of problems. As defined in the UK framework, "it involves the demonstration of high levels of knowledge, a high level of work expertise in job roles... Qualifications at this level are appropriate for people working as higher grade technicians, professionals or managers". Meanwhile, the Mexico framework states that "it involves the application of a considerable range of fundamental principles and complex techniques in a wide variety of contexts which are often unpredictable...high degree of personal autonomy, and frequently responsibility for allocating resources and for analysis, diagnosis, design, planning, execution and evaluation".

\subsection{Quality in Education and Training Sectors}

Grönroos (1984) states that the service quality model has three components: technical quality, functional quality, and image quality. Technical quality pertains to the actual results or the quality of services provided. It can be 
seen as that which customers obtain from receiving the services. Technical quality is important, and it is the main criterion being valued by customers. Meanwhile, functional quality pertains to how customers experience the service delivery process, resulting from interaction with the employee of the service provider and appropriate resources. Functional quality is concerned with how a service is provided as well as the customer experience obtained through the delivery process. The image of the organisation is highly influenced by and depends on both technical quality and functional quality.

Research on service quality has produced several measurement intruments such as SERVQUAL (Parasuraman, Zeithaml, \& Berry, 1991), SERVPERV (Cronin \& Taylor, 1994), Higher Education Performance or HEdPERF (Abdullah, 2006a), EduQUAL (Mahapatra \& Khan, 2007), Service Quality Measurement in Higher Education in India or SQM-HEI (Senthilkumar \& Arulraj, 2011), and EDUSERVE (Ramseook-Munhurrun, Naidoo, \& Nundlall, 2010). Every single instrument has its own pros and cons, and remains to be a subject of argument among authors. Dimensions of the construct measured differ depending on the subject, the method and context of the study.

Table 2. Service quality measurement instrument

\begin{tabular}{ll}
\hline $\begin{array}{c}\text { Measurement } \\
\text { Scale }\end{array}$ & \multicolumn{1}{c}{ Quality Dimension } \\
\hline SERVQUAL & Tangibles; Reliability; Responsiveness; Assurance; and Empathy. \\
SERVPERV & Tangibles; Reliability; Responsiveness; Assurance; and Empathy. \\
HEdPERF & Non-academic aspects; Academic aspects; Reputation; Access; and Understanding. \\
EduQUAL & Learning outcomes; Responsiveness; Physical facilities; Personality development; \\
& and Academics. \\
SQM-HEI & Teaching methodology; Environmental change in study factor; Disciplinary measure \\
& taken; Placement-related activities; and Overall rating of service quality and \\
& satisfaction level. \\
EDUSERVE & Empathy; School facilities; Reliability; Responsiveness ; and Assurance-discipline. \\
\hline
\end{tabular}

Table 2 shows the comparison of constructs measured by several instruments. The first two, SERVQUAL and SERVPERF, are generic instruments used across sectors. Those instruments have been used in the educational area, with amendments to fit the condition and circumstance of research (Gallifa \& Batalle, 2010; Ramseook-Munhurrun et al., 2010; Sahney et al., 2004; Sahney, Banwet, \& Karunes, 2008; Yeo, 2008). The others are established for the educational sector. Higher Education Performance (HEdPERF) was developed as an instrument for service quality that included the accurate factors of service quality within the higher educational sector (Abdullah, 2006a). The result revealed that student perceptions of service quality can be summarised as a six-factor structure consisting of: non-academic; academic; reputation; access; programme issues; and understanding. EduQUAL has been developed to suit the technical education system which is developed through identification of service elements that are appropriate for numerous customers (Mahapatra \& Khan, 2007). SQM-HEI was prepared for assessing service quality at the University in India. EDUSERVE was built based on SERVQUAL, and was applied in the study of service quality in schools in Mauritius (Ramseook-Munhurrun et al., 2010). 
Table 3. Service quality dimension in the education sector by various authors

\begin{tabular}{|c|c|c|c|c|c|c|c|c|c|c|c|c|}
\hline \multirow[t]{2}{*}{ No } & \multirow{2}{*}{$\begin{array}{l}\text { Quality } \\
\text { Dimension }\end{array}$} & \multicolumn{11}{|c|}{ Author } \\
\hline & & $\begin{array}{l}\text { Aldridge } \\
\text { and } \\
\text { Rowley } \\
\text { (1998) }\end{array}$ & $\begin{array}{l}\text { Sangeeta } \\
\text { et al } \\
\text { (2004) }\end{array}$ & $\begin{array}{l}\text { Hamida } \\
\text { het al. } \\
\text { (2004) }\end{array}$ & $\begin{array}{l}\text { Stefan et } \\
\text { al. } \\
\text { (2004) }\end{array}$ & $\begin{array}{l}\text { Ronnie } \\
\text { and } \\
\text { Ron } \\
\text { (2005) }\end{array}$ & $\begin{array}{l}\text { Firdaus } \\
\text { A. } \\
\text { (2006) }\end{array}$ & $\begin{array}{l}\text { Douglas } \\
\text { et al. } \\
(2008)\end{array}$ & $\begin{array}{l}\text { Munteanu } \\
\text { et al.(2010) }\end{array}$ & $\begin{array}{l}\text { Gruber et } \\
\text { al.(2010) }\end{array}$ & $\begin{array}{l}\text { Maria et } \\
\text { al. (2010) }\end{array}$ & $\begin{array}{l}\text { Prabha et } \\
\text { al. (2010) }\end{array}$ \\
\hline 1. & $\begin{array}{l}\text { Curriculum/ } \\
\text { content }\end{array}$ & $\mathrm{X}$ & $\mathrm{X}$ & $\mathrm{X}$ & & $\mathrm{X}$ & & & $\mathrm{X}$ & $\mathrm{X}$ & $\mathrm{X}$ & \\
\hline 2. & $\begin{array}{l}\text { Campus } \\
\text { facilities }\end{array}$ & $\mathrm{X}$ & & $\mathrm{X}$ & $\mathrm{X}$ & & & $X$ & & $X$ & $\mathrm{X}$ & $\mathrm{X}$ \\
\hline 3. & $\begin{array}{l}\text { Teaching } \\
\text { practices } \\
\text { /delivery }\end{array}$ & $\mathrm{X}$ & & $\mathrm{X}$ & $\mathrm{X}$ & $X$ & & & & & & \\
\hline 4. & $\begin{array}{l}\text { Courses } \\
\text { offered }\end{array}$ & $\mathrm{X}$ & & $\mathrm{X}$ & $\mathrm{X}$ & & $\mathrm{X}$ & & & & & \\
\hline 5. & $\begin{array}{l}\text { The academic } \\
\text { personnel }\end{array}$ & & & $X$ & & & & & & $X$ & $X$ & \\
\hline 6. & $\begin{array}{l}\text { Support } \\
\text { Services }\end{array}$ & & & $X$ & & & & & $\mathrm{X}$ & $X$ & & \\
\hline 7. & $\begin{array}{l}\text { Library } \\
\text { resources }\end{array}$ & & & & $X$ & & & & & $X$ & $X$ & \\
\hline 8. & Administration & & & $X$ & & & & & & $X$ & $\mathrm{X}$ & \\
\hline 9. & $\begin{array}{l}\text { Post-study } \\
\text { factors / career } \\
\text { prospects }\end{array}$ & & & & X & & & & & & $X$ & \\
\hline 10. & $\begin{array}{l}\text { The location of } \\
\text { the institute }\end{array}$ & & & & & & & & & $\mathrm{X}$ & $\mathrm{X}$ & \\
\hline
\end{tabular}

Research on service quality in the education sector has concentrated on various dimensions. Table 3 shows a comparison of the quality dimensions discussed by several scholars. Although each scholar presents the differences in terms of items measured, it can be concluded that all studies enclosed a majority of the important factors for students including academics, facilities, and support services. In this work, the instrument was adopted from several studies and was adjusted to cover most of the important aspects in the skills training institutions (Douglas et al., 2006; Lagrosen, Seyyed-Hashemi, \& Leitner, 2004; Maimunah, Kaka, \& Finch, 2009; Parker, 2008; Sohail \& Shaikh, 2004; Telford \& Masson, 2005; Tsinidou et al., 2010).

\subsection{Students' Satisfaction}

The student is considered the main customer among a number of customers and stakeholders in the training and educational institutions (Abdullah, 2006a). There are important items to consider when measuring student response to service quality. Student response is valuable for performance enhancement, including the teaching aspect and curriculum design (Nair et al., 2011). Sirvanci (1996) as mentioned in (Mahapatra \& Khan, 2007) specifies that the main customers of learning institutions are students and they play multiple roles in the institution. Students are the output of the teaching and learning process, the internal customers for campus facilities and course material delivery and at the same time they are the workers of the learning process. They have to do their assignments and revisions to ensure the learning process is effective.

Maimunah et al. (2009) observe that students' satisfaction is predicted by three factors, namely performance of trainer, service delivery, and support facilities. This conclusion is in line with that of Hill et al. (2003) who found in research on student's quality experience in higher education that the lecturer and the support system are the 
most significant predictors. Quality of lecturer includes teaching process, how they give feedback to students, and their relationship with students.

Jalali, Islam, and Ariffin (2011) identify variables that influenced student satisfaction in a university in Malaysia. They observed that academic factors are more important than support function factors. Academic functions are not restricted to the teaching process, but include aspects that can develop students in many ways. Douglas et al. (2006) measured UK university students' satisfaction also observing that the most important factors that determine student satisfaction are those related to the teaching and learning process.

Nevertheless, Douglas et al. (2006) found that the less important factors were those linked to the physical facilities which contradict the results presented by Maimunah et al. (2009) who identified the institution's facilities as the most important aspect. They note that the physical infrastructure is an important factor that influences prospective students when deciding on which institution to enroll. Once they have enrolled in the institution, the academic activities become more crucial. Though, this research only involves a university in the UK that is already equipped with modern facilities, these factors are not an issue for students. Meanwhile, the finding of Maimunah et al. (2009) in the context of Malaysia, the equipment and facilities factors are vital from the students' viewpoint.

In conclusion, as primary customers, students' satisfaction is crucial to the survival of any learning organisation. Factors that determine student satisfaction comprise both academic and non-academic. Therefore, this research will focus on both aspects.

\section{Research Methods}

\subsection{Data Collection}

A questionnaire was used to evaluate student opinions towards service quality as well as overall satisfaction. The instrument was designed based on an extensive literature review of previous research (Douglas et al., 2006; Lagrosen et al., 2004; Maimunah et al., 2009; Parker, 2008; Sohail \& Shaikh, 2004; Telford \& Masson, 2005; Tsinidou et al., 2010) and experts' opinion. Content validation was carried out with three practicioners in skills training, and the questionnaires were revised according to their feedback. The service quality construct included: campus environment; physical facilities; training equipment; instructor; curriculum; training delivery; support services; library; and management of the institute.

A questionnaire with a five-point Likert scale was used to collect responses for each construct of the research model. Questionnaires were designed based on the measurement scale adopted from previous studies (Douglas et al., 2006; Lagrosen et al., 2004; Maimunah et al., 2009; Parker, 2008; Sohail \& Shaikh, 2004; Telford \& Masson, 2005; Tsinidou et al., 2010). Table 4 presents the constructs and items in the instrument.

Table 4. List of constructs and respective items

\begin{tabular}{ll}
\hline No. & \multicolumn{1}{c}{ Constructs } \\
\hline B1 Campus Environment & B1.1 Overall physical appearance of the institute. \\
& B1.2 Cleanliness of the institute. \\
& B1.3 Layout of building, classroom and workshop. \\
& B1.4 Environment conducive for learning
\end{tabular}

B2 Physical Facilities

B3 Training Equipment
B2.1 Conducive classroom.

B2.2 Conducive workshop.

B2.3 Sport and recreation facilities.

B2.4 Cafeteria

B2.5 Accomodations / hostel.

B3.1 Training equipment suitable to current technology.

B3.2 Training equipment suitable to training programme.

B3.3 Sufficient training equipment and materials. 
B3.4 Opportunity of every student to use training equipment.

B3.5 Equipment in good and working condition.

B4 Instructor

B5 Curriculum

B6 Training Delivery

B7 Support Service

B8 Library

B9 Management of institute

C Students overall satisfaction
B4.1 Knowledge of the subject.

B4.2 Skills in the subject.

B4.3 Effective two-way communication with student.

B4.4 Punctuality.

B4.5 Accessibility and availability

B5.1 Attractive content and ability to stimulate students' interest.

B5.2 Relation of training to practical work.

B5.3 Ability of training content to meet job market requirements.

B5.4 Provision of training content in the early training sessions

B6.1 Training schedule suitable and not burdensome to students.

B6.2 Effectiveness of training delivery.

B6.3 Use of appropriate language in training delivery.

B6.4 Quality training materials and notes.

B6.5 Assessment method.

B7.1 Good counceling services.

B7.2 Effective induction programme for new students.

B7.3 Safety and welfare of students.

B7.4 Effective career guidance services.

B7.5 Attitude of support staff.

B8.1 Availability of textbook and learning materials.

B8.2 Ease of borrowing process.

B8.3 User-friendliness.

B8.4 Suitable operation hours.

B9.1 Service provided within the time promised.

B9.2 Good keeping of students' record.

B9.3 Operating hours suitable with students' need.

B9.4 Effective feedback mechanisme and suggestion system.

B9.5Ability to address students' suggestion and feedback in a proper manner.

C1 Satisfaction towards overall training and service quality.

C2 Satisfied with the decision of selecting this institute.

C3 Meaningful and exciting experienced while study in this institute.

C4 Intention to pursue further studies in this institute.

C5 Recommend this institute to relatives or friends. 


\subsection{Data Analysis}

Partial Least Squares Structural Equation Modelling (PLS-SEM) using SmartPLS version 2.0 was selected as the statistical technique for this research to evaluate the influence of service quality on students' overall satisfaction. PLS-SEM was chosen as a method for this study because of the following reasons (Hair, Black, Babin, \& Anderson, 2010):

1) PLS-SEM is appropriate when the major concern of research is the prediction of dependent variables, as PLS produces latent variable scores that can be used to predict a model.

2) PLS places minimal limitations on the distribution characteristics and sample size.

3) PLS is a better means for an exploratory study.

\subsection{Demographic of the Respondents}

Table 5. Demographic information of the respondents

\begin{tabular}{llc}
\hline Total Respondents & & 419 \\
\hline Gender & Male & $367(87.6 \%)$ \\
& Female & $52(12.4 \%)$ \\
\hline Types of Institute & Public Institute & $276(65.9 \%)$ \\
& Private Institute & $143(34.1 \%)$ \\
\hline Institute & Public Institute A & $119(28.4 \%)$ \\
& Public Institute B & $87(20.8 \%)$ \\
& Public Institute C & $70(16.7 \%)$ \\
& Private Institute D & $57(13.6 \%)$ \\
& Private Institute E & $39(9.3 \%)$ \\
& Private Institute F & $37(8.8 \%)$ \\
& Private Institute G & $10(2.4 \%)$ \\
\hline
\end{tabular}

Table 5 shows the respondents' demographic information including gender, type of institute, and the institute itself. Total number of respondents is 419, 276 of whom are from public training institutes and 143 are from private institutes. Most of them are male, accounting for 87.6 percent of the total. This ratio characterises the student population in the training institutes that offer training programmes in the field of technical and engineering.

\section{Results}

The results of the study are reported in several sections.

\subsection{Measure and Assessment of Goodness of Measures}

The two main criteria used for testing goodness of fit measures are validity and reliability. Validity is the proof that the instrument used to measure a concept indeed measures the intended concept (Sekaran, 2003). Reliability is an indication of the stability and consistency with which the instrument measures the concept and hence confirms consistent measurement across time and various items in the instrument (Sekaran, 2003).

\subsection{Construct Validity}

Construct validity testifies to how well the results obtained from the use of the measure fit the theories around which the test is designed (Sekaran, 2003). Does the instrument tap the concept as theorised? This will be assessed by convergent and discriminant validity.

\subsection{Convergent Validity}

Convergent validity is the degree to which multiple items measuring the same concept are in agreement. Hair et al. (2010) suggests using factor loadings, composite reliability, and average variance extracted to assess 
convergence validity. Loading for all items exceeded the recommended value of 0.5 (see Hair et al., 2010).

Table 6. Result of measurement model

\begin{tabular}{|c|c|c|c|c|c|}
\hline Model Construct & Measurement Item & Loading & T-value & $\mathrm{CR}$ & AVE \\
\hline \multirow[t]{4}{*}{ Campus Environment (B1) } & B1.1 & 0.775 & 32.946 & 0.858 & 0.603 \\
\hline & B1.2 & 0.697 & 15.658 & & \\
\hline & B1.3 & 0.833 & 46.294 & & \\
\hline & B1.4 & 0.793 & 28.445 & & \\
\hline \multirow[t]{5}{*}{ Physical Facilities (B2) } & B2.1 & 0.735 & 21.911 & 0.844 & 0.520 \\
\hline & $\mathrm{B} 2.2$ & 0.722 & 21.346 & & \\
\hline & $\mathrm{B} 2.3$ & 0.730 & 24.802 & & \\
\hline & B2.4 & 0.707 & 20.984 & & \\
\hline & $\mathrm{B} 2.5$ & 0.711 & 25.212 & & \\
\hline \multirow[t]{5}{*}{ Training Equipment (B3) } & B3.1 & 0.841 & 53.042 & 0.914 & 0.681 \\
\hline & B3.2 & 0.834 & 44.157 & & \\
\hline & B3.3 & 0.854 & 54.404 & & \\
\hline & B3.4 & 0.759 & 26.735 & & \\
\hline & B3.5 & 0.836 & 53.072 & & \\
\hline \multirow[t]{5}{*}{ Instructor (B4) } & B4.1 & 0.839 & 39.514 & 0.910 & 0.669 \\
\hline & B4.2 & 0.856 & 44.500 & & \\
\hline & B4.3 & 0.786 & 29.932 & & \\
\hline & B4.4 & 0.818 & 38.478 & & \\
\hline & B4.5 & 0.789 & 28.972 & & \\
\hline \multirow[t]{4}{*}{ Curriculum (B5) } & B5.1 & 0.856 & 53.360 & 0.864 & 0.617 \\
\hline & B5.2 & 0.842 & 42.489 & & \\
\hline & B5.3 & 0.784 & 27.110 & & \\
\hline & B5.4 & 0.643 & 15.864 & & \\
\hline \multirow[t]{5}{*}{ Training Delivery (B6) } & B6.1 & 0.730 & 25.095 & 0.874 & 0.582 \\
\hline & B6.2 & 0.756 & 23.673 & & \\
\hline & B6.3 & 0.741 & 22.605 & & \\
\hline & B6.4 & 0.777 & 25.914 & & \\
\hline & B6.5 & 0.808 & 40.074 & & \\
\hline \multirow[t]{5}{*}{ Support Service (B7) } & B7.1 & 0.773 & 36.886 & 0.892 & 0.623 \\
\hline & B7.2 & 0.796 & 35.984 & & \\
\hline & B7.3 & 0.764 & 31.103 & & \\
\hline & B7.4 & 0.804 & 31.704 & & \\
\hline & B7.5 & 0.810 & 42.151 & & \\
\hline Library (B8) & B8.1 & 0.512 & 3.431 & 0.846 & 0.587 \\
\hline
\end{tabular}




$\begin{array}{llllll} & \text { B8.2 } & 0.848 & 40.235 & & \\ \text { B8.3 } & 0.864 & 39.870 & & \\ \text { Management (B9) } & \text { B8.4 } & 0.790 & 22.717 & & \\ & \text { B9.1 } & 0.826 & 47.911 & 0.914 & 0.681 \\ & \text { B9.2 } & 0.773 & 31.548 & & \\ \text { B9.3 } & 0.823 & 41.039 & & \\ \text { Overall Satisfaction } & \text { B9.4 } & 0.867 & 54.953 & & \\ \text { (C) } & \text { B9.5 } & 0.834 & 53.619 & & \\ & \text { C1 } & 0.814 & 41.881 & 0.899 & 0.642 \\ & \text { C2 } & 0.820 & 38.898 & & \\ \text { C3 } & 0.826 & 41.916 & & \\ & \text { C4 } & 0.716 & 18.336 & & \\ \text { C5 } & 0.826 & 48.038 & & \end{array}$

Notes. Composite reliability $(\mathrm{CR})=$ (square of the summation of the factor loadings $) /$ \{ (square of the summation of the factor loadings $)+$ (square of the summation error variances $)\}$; Average variance extracted (AVE) $=$ (summation of the square of the factor loadings) $/$ (summation of the square of the factor loadings) + (summation of the error variances) $\}$.

Composite reliability $(\mathrm{CR})$ value depicts the degree to which the construct indicators indicate the latent. From Table 6, CR ranged from 0.844 to 0.914 , which exceeded the recommended value of 0.7 (see Hair et al., 2010). Average variance extracted (AVE) measures the variance captured by the indicators relative to measurement error, and it should be greater than 0.50 to justify the use of a construct (Barclay et al., 1995). Table 6 shows that AVE ranged between 0.520 and 0.681 . The results reveal that all 10 constructs: campus environment, physical facilities, training equipment, instructor, curriculum, training delivery, support services, library, management, and overall satisfaction are all valid measures of their respective constructs based on their parameter estimates and statistical significance.

\subsection{Discriminant Validity}

Discriminant validity of the measures is the degree to which items are differentiated among constructs or the degree to which distinct concepts are measured. Discriminant validity can be assessed by examining the correlations between the measures of potentially overlapping constructs. Items should load more strongly on their own constructs in the model, and the average variance shared between the construct and other constructs (Compeau et al., 1999). 
Table 7. Discriminant validity of construct

\begin{tabular}{lllllllllll}
\hline Construct & 1 & 2 & 3 & 4 & 5 & 6 & 7 & 8 & 9 & 10 \\
\hline Physical Facilities & $\mathbf{0 . 7 2 1}$ & & & & & & & & & \\
Overall Satisfaction & 0.566 & $\mathbf{0 . 8 0 1}$ & & & & & & & & \\
Support Services & 0.538 & 0.627 & $\mathbf{0 . 7 8 9}$ & & & & & & & \\
Curriculum & 0.498 & 0.543 & 0.547 & $\mathbf{0 . 7 8 5}$ & & & & & & \\
Management & 0.553 & 0.628 & 0.688 & 0.486 & $\mathbf{0 . 8 2 5}$ & & & & & \\
Training Delivery & 0.480 & 0.569 & 0.601 & 0.660 & 0.551 & $\mathbf{0 . 7 6 3}$ & & & & \\
Training Equipment & 0.644 & 0.581 & 0.561 & 0.504 & 0.573 & 0.570 & $\mathbf{0 . 8 2 5}$ & & & \\
Campus Environment & 0.696 & 0.606 & 0.541 & 0.478 & 0.555 & 0.508 & 0.635 & $\mathbf{0 . 7 7 6}$ & & \\
Library & 0.509 & 0.518 & 0.630 & 0.421 & 0.596 & 0.461 & 0.419 & 0.445 & $\mathbf{0 . 7 6 6}$ & \\
Instructor & 0.426 & 0.515 & 0.460 & 0.623 & 0.474 & 0.657 & 0.491 & 0.475 & 0.316 & $\mathbf{0 . 8 1 8}$
\end{tabular}

Note. The diagonals (in bold) represent the square root of the average variance extracted (AVE) while the other entries represent the correlations between constructs.

Table 7 shows that the square root of the average variance extracted by the indicators measuring that construct is higher than the correlation for each construct indicating adequate discriminant validity. In total, the measurement model demonstrated adequate convergent validity and discriminant validity.

\subsection{Reliability Analysis}

Cronbach's alpha coefficient was used to assess inter-item consistency of measurement items.

Table 8. Result of reliability testing

\begin{tabular}{lccc}
\hline Model Construct & Loading Range & Cronbach's alpha & Number of items \\
\hline Campus Environment (B1) & $0.697-0.833$ & 0.780 & 4 \\
Physical Facilities (B2) & $0.707-0.735$ & 0.770 & 5 \\
Training Equipment (B3) & $0.759-0.854$ & 0.883 & 5 \\
Instructor (B4) & $0.786-0.856$ & 0.877 & 5 \\
Curriculum (B5) & $0.643-0.856$ & 0.788 & 4 \\
Training Delivery (B6) & $0.730-0.808$ & 0.820 & 5 \\
Support Services (B7) & $0.764-0.810$ & 0.849 & 7 \\
Library (B8) & $0.512-0.864$ & 0.758 & 4 \\
Management (B9) & $0.773-0.867$ & 0.882 & 5 \\
Overall Satisfaction (C) & $0.716-0.826$ & 0.860 & 5 \\
\hline
\end{tabular}

Table 8 summarises the loading and alpha values. All alpha values are above 0.7 (Table 8), and composite reliability value ranged from 0.844 to 0.914 (Table 6). Thus, internal consistency reliability is considered acceptable and the measurements are reliable.

\subsection{Hypothesis Testing}

Nine constructs were identified in the study: campus environment, physical facilities, training equipment, instructor, curriculum, training delivery, support services, library, and management. These factors were hypothesised as significant predictors of student satisfaction as follows:

H1: Campus environment is a significant predictor of student satisfaction. 
H2: Physical facilities is a significant predictor of student satisfaction.

H3: Training equipment is a significant predictor of student satisfaction.

H4: Instructor is a significant predictor of student satisfaction.

H5: Training curriculum is a significant predictor of student satisfaction.

H6: Training delivery is a significant predictor of student satisfaction.

H7: Support services is a significant predictor of student satisfaction.

H8: Library is a significant predictor of student satisfaction.

H9: Management of the institute is a significant predictor of student satisfaction.

The nine hypotheses generated were tested using path analysis.

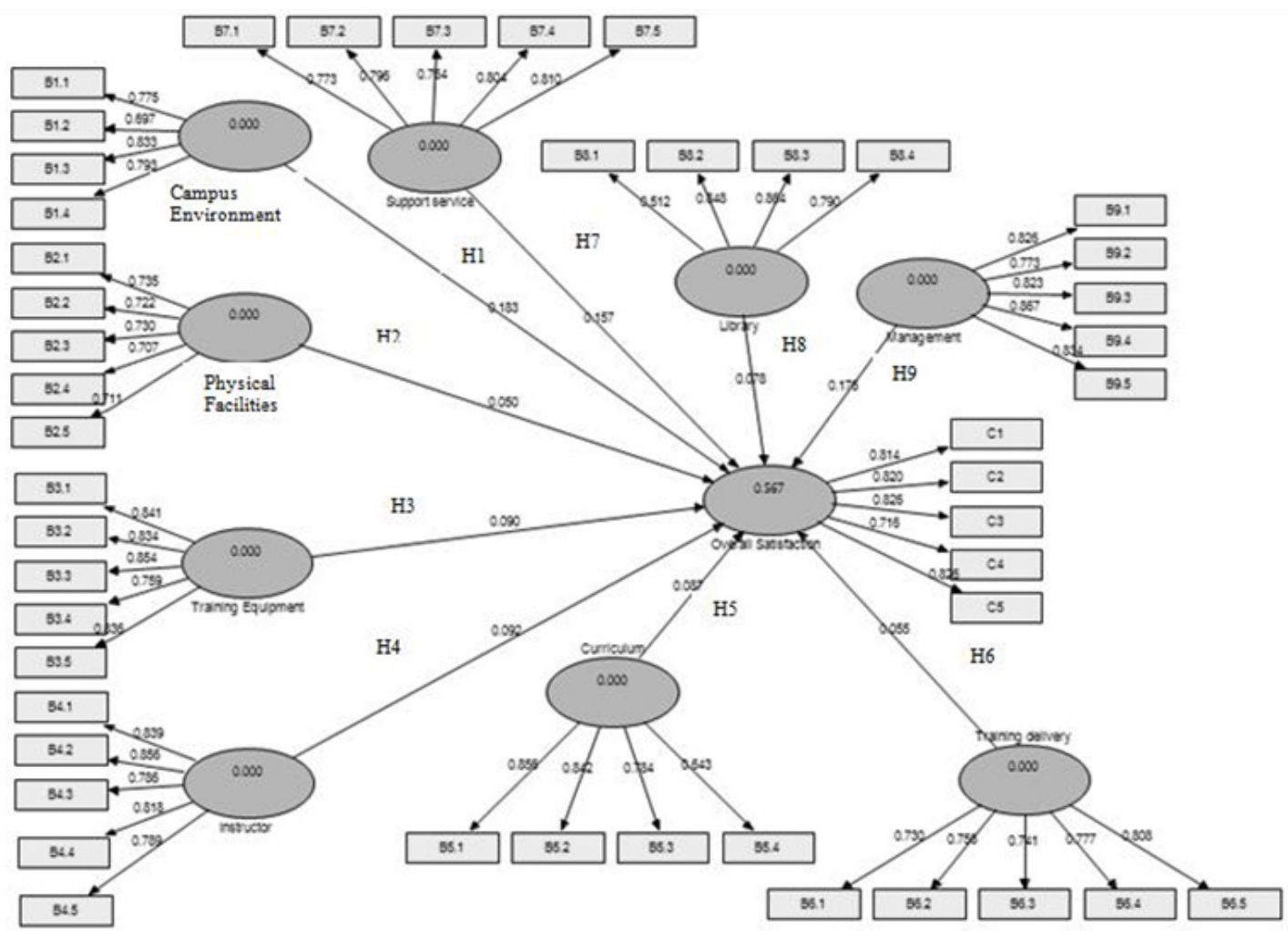

Figure 1. Results of the Path Analysis

Table 9. Path ccoefficients and hypothesis testing

\begin{tabular}{lllll}
\hline Hypothesis & Model Construct & Path Coefficient & t value & Supported \\
\hline H1 & Campus Environment $\rightarrow$ Satisfaction & 0.183 & $3.509^{* *}$ & Yes \\
H2 & Physical Facilities $\rightarrow$ Satisfaction & 0.050 & 0.934 & No \\
H3 & Training Equipment $\rightarrow$ Satisfaction & 0.090 & $1.851^{*}$ & Yes \\
H4 & Instructor $\rightarrow$ Satisfaction & 0.092 & $1.817^{*}$ & Yes \\
H5 & Curriculum $\rightarrow$ Satisfaction & 0.087 & $1.832^{*}$ & Yes \\
H6 & Training Delivery $\rightarrow$ Satisfaction & 0.055 & 0.886 & No \\
H7 & Support Services $\rightarrow$ Satisfaction & 0.157 & $2.565^{* *}$ & Yes \\
H8 & Library $\rightarrow$ Satisfaction & 0.078 & $1.793^{*}$ & Yes \\
H9 & Management $\rightarrow$ Satisfaction & 0.176 & $3.025^{* *}$ & Yes \\
\hline
\end{tabular}


The structural model indicates the causal relationships among constructs in the model which includes the estimates of the path coefficients, and the $\mathrm{R}^{2}$ value, which determine the prediction power of the model. Together, the $\mathrm{R}^{2}$ and the path coefficients indicate how well the data support the hypothesised model (Chin, 1998). Table 9 and Figure 1 show the results of the structural model from the PLS output. Campus environment $(\beta=0.183, p<$ $0.01)$, support service $(\beta=0.157, \mathrm{p}<0.01)$, management $(\beta=0.176, \mathrm{p}<0.01)$, training equipment $(\beta=0.09, \mathrm{p}<$ $0.05)$, instructor $(\beta=0.092, \mathrm{p}<0.05)$, curriculum $(\beta=0.087, \mathrm{p}<0.05)$, and library services $(\beta=0.078, \mathrm{p}<0.05)$ were positively related to students' overall satisfaction with $56.7 \%$ of the variance accounted for thus supporting $\mathrm{H} 1, \mathrm{H} 3, \mathrm{H} 4, \mathrm{H} 5, \mathrm{H} 7, \mathrm{H} 8$, and $\mathrm{H} 9$ of this study. Physical facilities $(\beta=0.05, \mathrm{p}>0.05)$ and training delivery $(\beta=$ $0.055, \mathrm{p}>0.05$ ) were not significant predictors of students' overall satisfaction, thus $\mathrm{H} 2$ and $\mathrm{H} 6$ were not supported.

\section{Discussion, Conclusion and Recommendations}

The results revealed that campus environment, management of the institute, and support services are the key drivers in the prediction of students' overall satisfaction. Although these three constructs are non-training factors, they have a big impact on students' daily life and serve as important determining factors. According to the service quality model by Grönroos (1984), this aspect is a functional quality concerned with how a service is provided as well as the customer experience obtained through the delivery process. This finding is in line with that of Abdullah (2006a), which indicates that access related to approachability, ease of contact, availability, and convenience significantly affects overall service quality. Previous studies show that aspects such as campus environment affect student learning (Pascarella \& Terenzini, 1991, Wiers-Jenssen, Stensaker, \& Grogaard, 2002). The campus environment will affect the impression the students have towards the institute. Campus environment includes campus appearance, cleanliness, layout of buildings, and workshops and classrooms that are conducive for training activity.

In addition, quality of management of the institute in managing services to students is also an important predictor of students' satisfaction. Efficiency and quality of management include the capabilities to deliver services as promised, good record-keeping of student's information, appropriate operating time, and effective management of feedback mechanism. All of these have a direct impact on supporting training activities. Management aspects such as strategic planning, setting rules and procedures, creating a system of assessment, accountability, quality management and human resource management determine the extent of the service quality offered by the institution. Thierauf, Klekamp, and Geeding (1977) defined management as a process that accommodates organisation input through planning, organising, directing and controling the output.

Students also paid attention to the support services provided at their institute, including counselling services, induction programmes, safety and welfare, career guidance, and attitude of the support staff. Student support service can be viewed as having various components, i.e. the elements that make up the system, their configuration, and the interaction between institutions and the students (Robinson, 1995). The elements are: personal contact between students and service provider, peer contact, the activity of giving feedback to individuals, additional materials, and access to campus facilities.

These findings do not mean that other service quality factors can be neglected by the training institutions. As mentioned by Abdullah (2006a), it is important to provide adequate service on all dimensions, and then possibly to ascertain which dimensions may require greater attention. Other than these three dimensions, prominent ones include ensuring the quality of skills training in total. These other support functions and facilities are important for determining the effectiveness of the teaching and learning process.

To ensure that instructors are proficient in facilitating knowledge and teaching skills, investment in training and development of instructor is a must. Instructors' competency is crucial to ensure the effectiveness of the students' learning process. Marzo-Navarro et al. (2005) found that the instructor, teaching process, and institution administration influence student satisfaction.

The curriculum must be able to provide students with opportunities to develop individual characteristics and skills that will positively impact their future career (Pomales-Garcia \& Liu, 2007). Institutions must make sure the method of training delivery is appropriate to the students' ability and not burdensome.

It is broadly accepted that availability and quality of physical facilities offer some clue of efficiency and quality of educational (Wilkinson \& Yussof, 2005). Institutes should be responsible for enhancing the quality of physical facilities including classrooms and workshops, training equipment, sports and recreational, cafeteria, and accommodations.

Another dimension pertains to support services such as counselling services, orientation programmes, student 
involvement and representation, appropriate regulations, safety and well-being, and career assistance. Support services include the library as well. The main indicators of quality in library services include the availability of books and training materials, ease of borrowing, kind staff, and convenient operating times. Tsinidou et al. (2010) highlight that the availability of books and other references are important factors in determining the quality of a library.

Nine dimensions of service quality in skills training institutions were assessed. These dimensions affected student satisfaction and determined which dimensions require improvement. It is important to offer satisfactory services and then possibly to determine which dimensions may need greater attention.

\section{References}

Abdullah, F. (2006a). The development of HEdPERF: A new measuring instrument of service quality for the higher education sector. International Journal of Consumer Studies, 30(6), 569-581. http://dx.doi.org/10.1111/j.1470-6431.2005.00480.x

Abdullah, F. (2006b). Measuring service quality in higher education: HEdPERF versus SERVPERF. Marketing Intelligence \& Planning, 24(1), 31-47. http://dx.doi.org/10.1108/02634500610641543

Abili, K., Thani, F. N., Mokhtarian, F., \& Rashidi, M. M. (2011). Assessing quality gap of university services. The Asian Journal on Quality, 12(2), 167-175. http://dx.doi.org/10.1108/15982681111158724

Barclay, D., Thompson, R., \& Higgins, C. (1995). The Partial Least Squares (PLS) Approach to Causal Modeling: Personal Computer Adoption and Use an Illustration. Technology Studies, 2(2), 285-309.

Brown, S. (2011). Bringing about positive change in the higher education student experience: A case study. Quality Assurance in Education, 19(3), 195-207. http://dx.doi.org/10.1108/09684881111158027

Chin, W. W. (1998). Issues and opinion on Structural Equation Modeling. Management Information Systems Quarterly, 22(1), 7-16.

Compeau, D. R., Higgins, C. A., \& Huff, S. (1999). Social cognitive theory and individual reactions to computing technology: A longitudinal-study. Management Information System Quarterly, 23(2), 145-158. http://dx.doi.org/10.2307/249749

Cronin, J. J., \& Taylor, S. A. (1994). SERVPERF versus SERVQUAL: Reconciling performance-based and perceptions-minus-expectations measurement of service quality. Journal of Marketing, 58(January), 125-131.

Debnath, R. M., \& Shankar, R. (2012). Improving service quality in technical education: Use of Interpretive Structural Modeling. Quality Assurance in Education, 20(4), 387-407. http://dx.doi.org/10.1108/09684881211264019

Douglas, J., Douglas, A., \& Barnes, B. (2006). Measuring student satisfaction at a UK university. Quality Assurance in Education, 14(3), 251-267. http://dx.doi.org/10.1108/09684880610678568

Gallifa, J., \& Batalle, P. (2010). Student perceptions of service quality in a multi-campus higher education system in Spain. Quality Assurance in Education, 18(2), 156-170. http://dx.doi.org/10.1108/09684881011035367

Ghazali, F. M. (2008). Faktor kualiti perkhidmatan Institut Pengajian Tinggi Swasta Malaysia dan Kaitannya Dengan Kepuasan Konsumer (Unpublished Doctoral dissertation, Universiti Putra Malaysia, Serdang).

Grönroos, C. (1984). A service quality model and its marketing implications. European Journal of Marketing, 18(4), 36-44. http://dx.doi.org/10.1108/EUM0000000004784

Hair, J., Black, W., Babin, B., \& Anderson, R. (2010). Multivariate Data Analysis. Upper Saddle River, NJ: Prentice-Hall.

Hattie, J. (1990). Performance indicators in education. Australian Journal of Education, 34(3), 249-276. http://dx.doi.org/10.1177/000494419003400304

Hill, Y., Lomas, L., \& MacGregor, J. (2003). Students' perceptions of quality in higher education. Quality Assurance in Education, 11(1), 15-20. http://dx.doi.org/10.1108/09684880310462047

Hittman, J. A. (1993). TQM and CQI in post-secondary education. Quality Progress, 26(10), 77-80.

Jalali, A., Islam, M. A., \& Ariffin, K. H. K. (2011). Service satisfaction: The case of a higher learning institution in Malaysia. International Education Studies, 4(1), 182-192. 
Lagrosen, S., Seyyed-Hashemi, R., \& Leitner, M. (2004). Examination of the dimensions of quality in higher education. Quality Assurance in Education, 12(2), 61-69. http://dx.doi.org/10.1108/09684880410536431

Mahapatra, S. S., \& Khan, M. S. (2007). A neural network approach for assessing quality in technical education: an empirical study. International Journal of Productivity and Quality Management Decision, 2(3), 287-306. http://dx.doi.org/10.1504/IJPQM.2007.012451

Maimunah, S., Kaka, A., \& Finch, E. (2009). Factors that influence student's level of satisfaction with regards to higher educational facilities services. Malaysian Journal of Real Estate, 4(1), 34-51.

Malaysian Qualification Agency. (2011). Malaysian Qualification Framework.

Marzo-Navarro, M., Pedraja-Iglesias, M., \& Rivera-Torres, M. P. (2005). Measuring customer satisfaction in summer courses. Quality Assurance in Education, 13(1), 53-65. http://dx.doi.org/10.1108/09684880510578650

McCoy, J. P., Chamberlain, D., \& Seay, R. (1994). The status and perceptions of university outcomes assessment in economics. The Journal of Economic Education, 25(4), 358-366. http://dx.doi.org/10.2307/1182985

Mollis, M., \& Marginson, S. (2002). The assessment of universities in Argentina and Australia: Between autonomy and heteronomy. Higher Education, 43, 311-330. http://dx.doi.org/10.1023/A:1014603823622

Nair, C. S., Murdoch, N., \& Mertova, P. (2011). Benchmarking the student experience: The offshore campus experience. The TQM Journal, 23(6), 585-597. http://dx.doi.org/10.1108/17542731111175211

O’Shea, S., Lysaght, P., \& Tanner, K. (2012). Stepping into higher education from the vocational education sector in Australia: Student perceptions and experiences. Journal of Vocational Education \& Training, 64(3), 1-17. http://dx.doi.org/10.1080/13636820.2012.691532

Owlia, M. S., \& Aspinwall, E. M. (1997). TQM in higher education-A review. International Journal of Quality \& Reliability Management, 14(5), 527-543. http://dx.doi.org/10.1108/02656719710170747

Parasuraman, A., Zeithaml, V. A., \& Berry, L. L. (1991). Refinement and reassessment of the SERVQUAL scale. Journal of Retailing, 67(4), 420-450.

Parker, E. L. (2008). Factors that contribute to a successful secondary vocational education program in The State of Mississippi (Unpublished Doctoral dissertation, The University of Southern Mississippi).

Pascarella, E. T., \& Terenzini, P. T. (1991). How College Affects Students: Findings and Insights from Twenty Years of Research. San Francisco: Jossey-Bass Inc.

Pomales-Garcia, C., \& Liu, Y. (2007). Excellence in engineering education: Views of undergraduate Engineering $\begin{array}{lllll}\text { students. Journal of } & \text { Engineering 253-262. }\end{array}$ http://dx.doi.org/10.1002/j.2168-9830.2007.tb00934.x

Ramseook-Munhurrun, P., Naidoo, P., \& Nundlall, P. (2010). A proposed model for measuring service quality in secondary education. International Journal of Quality and Service Sciences, 2(3), 335-351. http://dx.doi.org/10.1108/17566691011090062

Robinson, B. (1995). Research and pragmatism in learner support. In F. Lockwood (Ed.), Open and Distance Learning Today (pp. 221-231). London: Routledge.

Rowley, J. (2003). Designing student feedback questionnaires. Quality Assurance in Education, 11(3), 142-149. http://dx.doi.org/10.1108/09684880310488454

Sahney, S., Banwet, D. K., \& Karunes, S. (2004). A SERVQUAL and QFD approach to total quality education: A student perspective. International Journal of Productivity and Performance Management, 53(2), 143-166. http://dx.doi.org/10.1108/17410400410515043

Sahney, S., Banwet, D. K., \& Karunes, S. (2008). An integrated framework of indices for quality management in education: A faculty perspective. The TQM Journal, 20(5), 502-519. http://dx.doi.org/10.1108/17542730810898467

Sekaran, U. (2003). Research Methods for Business A Skill Building Approach. Singapore: John Wiley \& Sons, Inc.

Senthilkumar, N., \& Arulraj, A. (2011). SQM-HEI-determination of service quality measurement of higher education in India. Journal of Modelling in Management, 6(1), 60-78. http://dx.doi.org/10.1108/17465661111112502 
Shank, M. D., Walker, M., \& Hayes, T. (1995). Understanding professional service expectations: Do we know what our students expect in a quality education? Journal of Professional Services Marketing, 13(1), 71-89. http://dx.doi.org/10.1300/J090v13n01_08

Shelnutt, J. W., \& Buch, K. (1996). Using total quality principles for strategic planning and curriculum revision. Journal of Engineering Education, 85(3), 201-207. http://dx.doi.org/10.1002/j.2168-9830.1996.tb00234.x

Sohail, M. S., \& Shaikh, N. M. (2004). Quest for excellence in business education: A study of student impressions of service quality. The International Journal of Educational Management, 18(1), 58-65. http://dx.doi.org/10.1108/09513540410512163

Telford, R., \& Masson, R. (2005). The congruence of quality values in higher education. Quality Assurance in Education, 13(2), 107-119. http://dx.doi.org/10.1108/09684880510594364

Thakkar, J., Deshmukh, S. G., \& Shastree, A. (2006). Total quality management (TQM) in self-financed technical institutions: A quality function deployment (QFD) and force field analysis approach. Quality Assurance in Education, 14(1), 54-74. http://dx.doi.org/10.1108/09684880610643610

Thierauf, R. J., Klekamp, R. C., \& Geeding, D. W. (1977). Management principles and practices: A contingency and questionnaire approach. Out-of-Print Books on Demand, University Microfilms International, Ann Arbor, Michigan.

Tsinidou, M., Gerogiannis, V., \& Fitsilis, P. (2010). Evaluation of the factors that determine quality in higher education: An empirical study. Quality Assurance in Education, 18(3), 227-244. http://dx.doi.org/10.1108/09684881011058669

Tuck, R. (2007). An Introductory Guide to National Qualifications Frameworks: Conceptual and Practical Issues for Policy Makers. Geneva: Skills and Employability Department, International Labour Office (ILO).

Wiers-Jenssen, J., Stensaker, B., \& Grogaard, J. B. (2002). Student satisfaction: Towards an empirical deconstruction of the concept. Quality in Higher Education, 8(2), 183-195. http://dx.doi.org/10.1080/1353832022000004377

Wilkinson, R., \& Yussof, I. (2005). Public and private provision of higher education in Malaysia: A comparative analysis. Higher Education, 50(3), 361-386. http://dx.doi.org/10.1007/s10734-004-6354-0

Yeo, R. K. (2008). Brewing service quality in higher education: Characteristics of ingredients that make up the recipe. Quality Assurance in Education, 16(3), 266-286. http://dx.doi.org/10.1108/09684880810886277

Yunos, J. M., Ahmad, W. M. R. W., Kaprawi, N., \& Razally, W. (2006). System of Technical \& Vocational Education \& Training in Malaysia (TVET). Paper presented at the 2nd International TT-TVET EU-Asia-Link project Meeting, VEDC Malang.

Yusof, A. R. M. (2008). Educational service quality and student satisfaction at public higher educational institutions in Malaysia: An expectation-perception importance analysis (Unpublished Doctoral dissertation, Universiti Teknologi Mara, Shah Alam).

\section{Copyrights}

Copyright for this article is retained by the author(s), with first publication rights granted to the journal.

This is an open-access article distributed under the terms and conditions of the Creative Commons Attribution license (http://creativecommons.org/licenses/by/3.0/). 